\title{
Pengaruh Kejelasan Sasaran Anggaran, Sistem Pelaporan Terhadap Akuntabilitas Pemerintah Dan Komitmen Organisasi sebagai Variabel Moderating
}

\author{
Nurji ${ }^{1}$ \\ Fakultas Ekonomi dan Bisnis \\ Universitas Mataram, Indonesia. \\ Email: ojiknurji@gmail.com
}

\author{
Thatok Asmoni2 \\ Fakultas Ekonomi dan Bisnis \\ Universitas Mataram, Indonesia.
}

\section{Surasni ${ }^{3}$ \\ Fakultas Ekonomi dan Bisnis Universitas Udayana, Indonesia.}

\begin{abstract}
ABSTRAK
Tujuan dari penelitian ini adalah untuk mengetahui pengaruh kejelasan sasaran anggaran dan sistem pelaporan terhadap akuntabilitas kinerja pemerintah desa dan komitmen organisasi sebagai variabel moderating pada pemerintah desa. Metode analisis data menggunakan model regresi linear berganda dan uji residual untuk variabel moderating. Hasil penelitian ini menunjukkan bahwa secara simultan kejelasan sasaran anggaran, dan sistem pelaporan berpengaruh secara signifikan terhadap akuntabilitas kinerja instansi pemerintah desa. Secara parsial sistem pelaporan berpengaruh positif signifikan terhadap akuntabilitas kinerja instansi pemerintah desa, sedangkan variabel kejelasan sasaran anggaran tidak berpengaruh terhadap akuntabilitas kinerja instansi pemerintah desa di Kecamatan Sakra Barat Kabupaten Lombok Timur.
\end{abstract}

Kata Kunci : Kejelasan Sasaran Anggaran; Sistem Pelaporan; Komitmen Organisasi Akuntabilitas Kinerja Instansi Pemerintah.

\section{Effect of Clarity of Budget Goals, Reporting Systems on Government Accountability and Organizational Commitment as Moderating Variables}

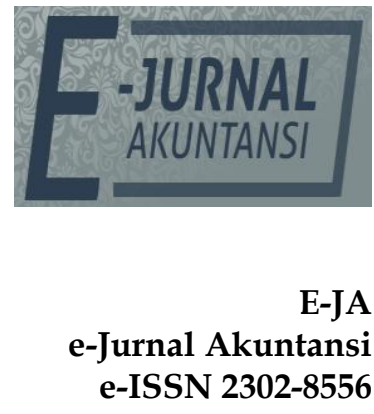

Vol. 29 No. 2

Denpasar, November 2019

Hal. 604-617

Artikel masuk: 25 Juni 2019

ABSTRACT

The purpose of this study is to determine the effect of clarity of budget targets and reporting systems on village government performance accountability and organizational commitment as a moderating variable on village government. The data analysis method uses multiple linear regression models and residual tests for moderating variables. The results of this study indicate that simultaneous clarity of budget targets and reporting systems significantly influences the performance accountability of village government agencies. Partially, the reporting system has a significant positive effect on the accountability of the performance of village government agencies, while the variable clarity of budget targets does not affect the accountability of the performance of village government agencies in the West Sakra District, East Lombok Regency.

Keywords: Budget Target Clarity; Reporting System; Organizational Commitment Performance Accountability Of Government Agencies.
Tanggal diterima: 18 November 2019 


\section{PENDAHULUAN}

Berawal dari tuntutan masyarakat agar terciptanya good governance dalam penyelenggaraan pemerintahan berbasis otonomi daerah di Indonesia, menjadikan akuntabilitas kinerja sebagai bagian yang sangat penting guna memberikan pertanggungjawaban atas rencana ataupun pelaksanaan anggaran yang berhak diketahui oleh publik. Dengan terbitnya Undang-Undang Nomor 6 tahun 2014 tentang Desa, beserta Permendagri No. 113 tahun 2014 tentang pengelolaan keuangan desa, yang menginginkan terwujudnya good governance pada penyelenggaraan pemerintahan desa.

Dengan adanya akuntabilitas publik, setiap aparat harus dapat menyajikan informasi yang benar dan lengkap untuk menilai kinerjanya baik yang dilakukan oleh masyarakat, organisasi/instansi kerjanya, maupun kelompok pengguna pelayanannya. Mardiasmo (2009:20) menyatakan bahwa akuntabilitas publik adalah kewajiban pihak pemegang amanah (agent) untuk memberikan pertanggungjawaban, menyajikan dan mengungkapkan segala aktivitasnya dan kegiatan yang menjadi tanggung jawabnya kepada pihak pemberi amanah (principal) yang memiliki hak dan kewenangan untuk menerima pertanggungjawaban tersebut.

Dari itu dapat disimpulkan bahwa sebagai entitas yang diberi wewenang, kepala desa sebagai salah satu entitas tersebut, maka dalam melaksanakan fungsi perencanaan, pelaksanaan, penatausahaan, dan pertanggungjawaban harus berstandar pada peraturan perundang-undangan dan untuk memastikan hal tersebut masyarakat dan pemerintah menjalankan fungsi pengawasan. Serta proses penganggaran mulai dari perencanaan, penyusunan, dan pelaksanaan harus benar-benar dapat dilaporkan dan dipertanggungjawabkan kepada Pemerintah Daerah dan masyarakat.

Keterbatasan SDM dan kebiasaan yang berjalan selama ini harus dirubah dan diperbaikan sehingga kultur good village governance dapat merasuk ke dalam administrasi dan birokrasi desa (Syukri, 2008). Dalam kaitan ini maka responsibilitas, transparansi dan akuntabilitas pengelolaan keuangan desa diartikan sebagai bagian dari suatu system pengelolaan keuangan daerah yang menyediakan informasi keuangan yang terbuka bagi masyarakat dalam rangka mewujudkan penyelenggaraan pemerintahan yang baik dan mempertanggungjawabkan pengelolaan sumber daya serta pelaksanaan kebijakan yang dipercayakan kepada unit organisasi pemerintah dalam rangka pencapaian tujuan yang telah ditetapkan melalui laporan keuangan pemerintah secara periodik (Surya, 2013:3)

Mardiasmo (2009:21) menyatakan dalam melaksanakan pemerintahan, pemerintah desa berkewajiban melakukan dua jenis pertanggungjawaban, yaitu pertama pertanggungjawaban vertikal adalah pertanggungjawaban kepada otoritas yang lebih tinggi, kedua pertanggungjawaban horizontal adalah pertanggungjawaban kepada masyarakat luas. Kedua jenis pertanggungjawaban tersebut merupakan elemen penting dalam proses akuntabilitas. Adapun penanggung jawab penyusunan Laporan Akuntabilitas Kinerja Instansi Pemerintah adalah pejabat yang secara fungsional bertanggungjawab melayani fungsi administrasi di instansi masing-masing. 
Pada konteks pemerintah desa, sasaran anggaran tercakup dalam rencana Rencana Strategis (Renstra) dan Rencana Pembangunan Jangka Menengah Desa (RPJMDes) lima tahunan dan Rencana Kerja Pembangunan Desa (KPDes). Adanya sasaran anggaran yang jelas akan memudahkan individu untuk menyusun target-target anggaran. Selanjutnya target anggaran yang disusun sesuai dengan sasaran yang ingin dicapai organisasi. Dengan demikian, kejelasan sasaran anggaran akan mempermudah aparat pemerintah daerah (Pangumbalerang \& Pinatik, 2014). Salah satu penyebab tidak efektif dan efisiennya anggaran dikarenakan ketidakjelasan sasaran anggaran yang mengakibatkan aparat pemerintah daerah mengalami kesulitan dalam penyusunan target-target anggaran ( Suwandi, 2013).

Sasaran anggaran berimplikasi pada aparat untuk menyusun anggaran sesuai dengan sasaran yang ingin dicapai instansi pemerintah. Selanjutnya, hal ini akan menurunkan perbedaan antara anggaran yang disusun dengan estimasi terbaik bagi organisasi ( Suhartono \& Solichin, 2006). Selain itu, Wahyuni et al., (2014) menyatakan bahwa tercapainya sasaran anggaran akan menentukan kualitas atau kinerja dari pemerintah daerah. Kebijakan yang ada pada daerah yang satu dengan daerah yang lain pasti berbeda, sehingga sasaran anggaran dan tingkat akuntabilitas suatu daerah juga berbeda.

Perwujudan pertanggungjawaban kinerja dimaksud dituangkan dalam bentuk laporan kinerja instansi pemerintah, yang bertujuan untuk meningkatkan pelaksanaan pemerintahan yang lebih berdaya guna, berhasil guna, bersih bertanggungjawab, dan sebagai wujud pertanggungjawaban dalam mencapai visi dan tujuan instansi pemerintah. Laporan kinerja instansi pemerintah juga dimaksudkan untuk memotivasi instansi pemerintah untuk memperbaiki perencanaan dan program, mobilisasi sumber daya, manajemen dan penganggaran, desain, serta implementasi proyek dari waktu ke waktu agar tercipta peningkatan kinerja instansi pemerintah secara terus menerus dan terciptanya good governance pemerintahan desa.

Perjanjian kinerja disusun berpedoman pada Indikator Kinerja Utama (IKU) yang telah bersinergi dengan Rencana Strategis (Renstra) dan Rencana Pembangunan Jangka Menengah Desa (RPJMDes) lima tahunan. Kemudian dilakukan pengukuran kinerja dengan cara membandingkan realisasi kinerja dengan target yang telah ditetapkan sehingga capaian kinerja dapat diketahui dan selanjutnya dituangkan dalam bentuk laporan kinerja instansi pemerintah.

Kenis (1979:709) mengatakan terdapat beberapa karakteristik sistem penganggaran. Salah satu karakteristik anggaran adalah kejelasan sasaran anggaran. Pada konteks pemerintah desa, sasaran anggaran tercakup dalam Rencana Pembangunan Jangka Menengah Desa (RPJMDes) dan Rencana Kerja Pembangunan Desa (RKPDes). Kenis (1979:709-710) mengatakan, adanya sasaran anggaran yang jelas akan memudahkan individu untuk menyusun target-target anggaran. Selanjutnya target-target anggaran yang disusun akan sesuai dengan sasaran yang ingin dicapai organisasi.

Pengelolaan pemerintah desa yang akuntabel, tidak bisa lepas dari anggaran pemerintah daerah, sistem pengendalian dan pelaporan. Hal ini sesuai dengan pendapat Mardiasmo (2009:24) yang menyatakan bahwa wujud dari penyelenggaraan otonomi daerah adalah pemanfaatan sumber daya yang 
dilakukan secara ekonomis, efisien, efektif, adil dan merata untuk mencapai akuntabilitas publik. Pemerintah selaku pengelola dana publik harus mampu menyediakan informasi keuangan yang disajikan secara akurat, relevan, konsisten, dan dapat dipercaya. Lembaga Administrasi Negara (LAN) dan Badan Pengawas Keuangan dan Pembangunan BPKP mengemukakan laporan yang baik adalah laporan yang harus disusun secara objektif, jujur, dan transparan (BPKP, 2011).

Beberapa hasil kajian sebelumnya seperti penelitian Susanto, (2018); Erwin, (2013); Supangkat, (2012); Riantiarno \& Azlina, (2011); Arifin, (2012); Wardhana, (2015); Hafiz, (2016) menemukan bahwa kejelasan sasaran anggaran, pengendalian akuntansi dan sistem pelaporan berpengaruh positif dan signifikan terhadap akuntabilitas kinerja instansi pemerintah baik secara parsial maupun. Sementara penelitian yang dilakukan Septiyani, (2010); Harini, (2014) menemukan hasil yang berbeda dimana kejelasan sasaran anggaran sebelum dan sesudah dimoderasi dengan komitmen organisasi mempunyai pengaruh negatif signifikan terhadap AKIP. Sejalan dengan hal tersebut, Heptariani et al., (2012) penelitian menemukan bahwa kejelasan sasaran anggaran terdapat pengaruh positif terhadap akuntabilitas kinerja pemerintah daerah namun pengendalian akuntansi, sistem pelaporan, dan motivasi kerja tidak berpengaruh terhadap akuntabilitas kinerja. Hal itu sejalan dengan penelitian yang dilakukan ( Satriajaya et al., (2018) menemukan bahwa penyimpangan terjadi karena pelaku menerima berbagai tekanan dan keberadaan diskresi dan inkonsistensi kebijakan menjadi penyebab terjadinya legalitas kleptokrasi.

Adanya perbedaan hasil penelitian tentang pengaruh kejelasan sasaran anggaran dan sistem pelaporan terhadap akuntabilitas kinerja pemerintah dan komitmen organisasi, maka menjadi peluang yang menarik untuk diteliti kembali. Adapun rumusan masalah dari penelitian ini adalah sebagai berikut : 1 . Apakah kejelasan sasaran anggaran dan sistem pelaporan berpengaruh terhadap akuntabilitas kinerja pemerintah desa baik secara parsial maupun simultan, 2. Apakah komitmen organisasi dapat memoderasi hubungan antara kejelasan sasaran anggaran dan sistem pelaporan dengan akuntabilitas kinerja pemerintah desa di Kecamatan Sakra Barat Kabupaten Lomok Timur. Sedangkan tujuan penelitian ini adalah : 1 . Untuk menguji dan menganalisis pengaruh kejelasan sasaran anggaran dan sistem pelaporan terhadap akuntabilitas kinerja pemerintah pemerintah desa baik secara parsial maupun simultan. 2. Untuk menguji dan menganalisis komitmen organisasi dapat memoderasi hubungan antara kejelasan sasaran anggaran dan sistem pelaporan dengan akuntabilitas kinerja pemerintah pemerintah desa di Kecamatan Sakra Barat Kabupaten Lomok Timur.

Goal-setting theory ini adalah teori yang membicarakan tentang pengaruh penetapan tujuan, tantangan, dan umpan balik terhadap kinerja. Goal setting theory menunjukkan adanya keterkaitan antara tujuan dan kinerja seseorang terhadap tugas ( Locke, 1968). Berdasarkan teori ini suatu individu menentukan tujuan atas perilakunya pada masa depan dan tujuan itu akan memberi pengaruh terhadap perilaku orang tersebut Davis (dalam Irmawati, 2004). Adanya tujuan menentukan seberapa besar upaya yang dilakukan seseorang, semakin tinggi komitmen yang dimiliki aparat terhadap tujuannya akan 
mendorong aparat tersebut melakukan upaya yang lebih maksimal dalam pencapaian tujuan (Arthana et al., 2016).

Agency Theory menyatakan bahwa hubungan keagenan merupakan sebuah persetujuan (kontrak) di antara dua pihak, yaitu principal dan agent, dimana principal memberi wewenang kepada agent untuk mengambil keputusan atas nama principal ( Jensen \& Meckling 1976). Dalam penelitian ini Agency Theory dimaknai sebagai akuntabilitas publik, dimana dengan adanya kewajiban pihak pemegang amanah (agent) untuk memberikan pertanggungjawaban, menyajikan, melaporkan dan mengungkapkan segala aktivitas dan kegiatan yang menjadi tanggungjawabnya kepada pihak pemberi amanah (principal) yang memiliki hak dan kewenangan untuk meminta pertanggungjawaban tersebut.

Mdel penelitian sebagai landasan berfikir menunjukkan dari sudut mana masalah yang telah disoroti dan memberikan suatu pandang sistematis mengenai gejala dengan merincikan hubungan antar variabel-variabel dengan tujuan menjelaskan gejala-gejala tertentu dari penelitian yang diteliti. Adapun hubungan antara variabel pada penelitian ini dapat dilihat pada gambar. 1 :

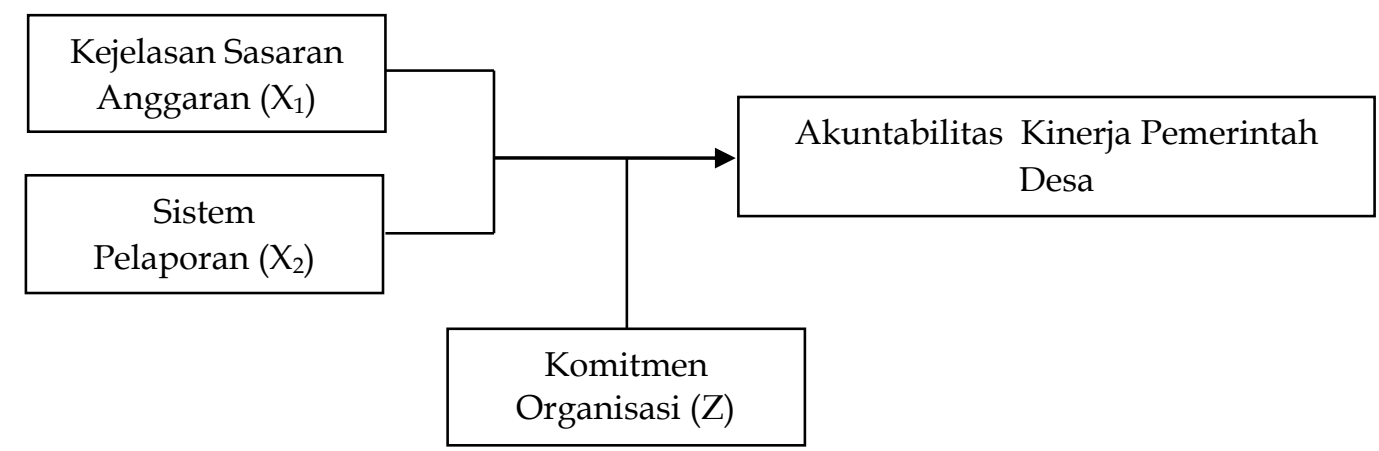

Gambar 1. Model Penelitian

Sumber : Data Penelitian, 2018

Melalui model penelitian di atas, dapat diketahui bahwa dalam penelitian ini terdiri dari beberapa variabel yaitu variabel independen, moderating dan dependen. Variabel independen dalam penelitian ini adalah kejelasan sasaran anggaran dan sistem pelaporan. Sedangkan variabel dependennya adalah akuntabilitas pemerintah desa dan komitmen organisasi sebagai variabel moderasi.

\section{METODE PENELITIAN}

Penelitian ini dirancang sebagai penelitian kausal dengan pendekatan kuantitatif, dengan teknik pengumpulan data menggunakan kuesioner. Jenis data penelitian ini adalah data primer yaitu data yang berasal dari sumber yang asli dan dikumpulkan secara khusus untuk menjawab pertanyaan atau pernyataan penelitian. Populasi dalam penelitian ini adalah seluruh Satuan Kerja Perangkat Desa di Kecamatan Sakra Barat yang berjumlah 19. Setiap instansi diwakili oleh 4 orang dan sebagian diwakili oleh 5 orang pegawai yang terlibat langsung dalam penyusunan akuntabilitas kinerja instansi pemerintah, dengan jumlah responden sebanyak 83 orang. Seluruh data yang diperoleh peneliti diolah menggunakan software SPSS, oleh karena itu, Sebelum dilakukan analisis data maka perlu 
dilakukan uji atas instrumen pertanyaan melalui uji validitas, reliabilitas dan uji asumsi klasik.

Pengujian hipotesis pertama pada penelitian ini dilakukan dengan model regresi linear berganda yang bertujuan untuk menguji pengaruh antara satu variabel dependen dengan dua atau lebih variabel independen. Persamaan regresi berganda dari penelitian ini dirumuskan sebagai berikut: $\mathrm{Y}=\mathrm{a}+\mathrm{b} 1 \mathrm{X} 1+\mathrm{b} 2 \mathrm{X} 2+\varepsilon$

Keterangan:

$\mathrm{Y}=$ Akuntabilitas Kinerja Instansi Pemerintah

a $\quad=$ konstansta

b1 = Koefisien regresi Kejelasan Sasaran Anggaran

b2 = Koefisien regresi Sistem Pelaporan

$\mathrm{X} 1=$ Kejelasan Sasaran Anggaran

$\mathrm{X} 2=$ Sistem Pelaporan

$\varepsilon=$ standar error pada tingkat $5 \%$

Untuk menjawab hipotesis kedua peneliti melakukan model uji residual. Uji residual dilakukan untuk menghindari terjadinya multikolinieritas pada model persamaan regresi. Uji residual menggunakan konsep ketidakcocokkan, yaitu hipotesis kedua diterima jika terdapat ketidakcocokkan yang berasal dari deviasi hubungan linear antar variabel independen (Ghozali, 2016:228). Seluruh variabel independen harus diregresikan dengan variabel moderating.

$\mathrm{Z}=\mathrm{a}+\mathrm{b} 1 \mathrm{X} 1+\mathrm{b} 2 \mathrm{X} 2+\varepsilon$

$|\varepsilon|=a+b 2 Y$

Keterangan:

$Z=$ Komitmen Organisasi

$\mathrm{Y}=$ Akuntabilitas Kinerja Instansi Pemerintah

$\mathrm{a}=$ Konstanta.

b1 $=$ Koefisien regresi Kejelasan Sasaran Anggaran

b2 $=$ Koefisien regresi Sistem Pelaporan

X1 = Kejelasan Sasaran Anggaran

$\mathrm{X} 2$ = Sistem Pelaporan

$\varepsilon=$ Error

$|\boldsymbol{\varepsilon}|=$ Absolut Error term

Persamaan uji residual ini menggambarkan apakah variabel komitmen organisasi merupakan variabel moderasi, yang ditunjukkan dengan nilai koefisien $\beta 4$. Uji residual dalam hal ini dapat memperlihatkan apakah suatu variabel dapat disebutkan sebagai variabel moderating.

Jika P Value (Sig) < 0,05 dan nilai koefisien parameternya negatif, maka suatu variabel dapat disebut sebagai variabel moderating.

Jika apabila P Value (Sig) > 0,05 dan nilai koefisien parameternya positif, maka suatu variabel tidak dapat disebut sebagai variabel moderating.

\section{HASIL DAN PEMBAHASAN}

Berdasarkan hasil tabulasi data pada 83 kuesioner yang telah dikumpulkan, maka dapat dijelaskan jawaban responden terhadap pertanyaan yang terdapat pada kuesioner penelitian. Pada variabel kejelasan sasaran anggaran nilai rata- 
rata (mean) 4,03, sistem pelaporan nilai rata-rata (mean) 4,11, komitmen organisasi nilai rata-rata (mean) 4,23 dan akuntabilitas kinerja instansi pemerintah nilai ratarata (mean) 4,63. Hal ini menunjukkan bahwa dari setiap variabel, responden cenderung memilih jawaban mendekati nilai 4,00, yang berarti bahwa responden telah mendeskripsikan kejelasan sasaran anggaran, sistem pelaporan, dan akuntabilitas kinerja instansi pemerintah telah berjalan dengan cukup baik pada instansi responden bekerja.

Persepsi responden mengenai kejelasan sasaran anggaran yaitu : distribusi jawaban responden dari pertanyaan ada kejelasan sasaran anggaran pada satuan kerja ini. Dari 83 responden, 14 orang (16.9\%) menyatakan sangat setuju, 56 orang $(67.5 \%)$ menyatakan setuju dan sisanya 13 orang $(15.7 \%)$ netral, 17 orang $(20.5 \%)$ menyatakan sangat setuju, 52 orang $(62.7 \%)$ menyatakan setuju dan sisanya 14 orang $(16.9 \%)$ netral, 10 orang $(12.0 \%)$ menyatakan sangat setuju, 62 orang $(74.7 \%)$ menyatakan setuju dan sisanya 11 orang $(13.3 \%)$ netral, 19 orang $(22.9 \%)$ menyatakan sangat setuju, 55 orang (66.3\%) menyatakan setuju dan sisanya 8 orang $(9.6 \%)$ netral, dan 1 orang $(1.2 \%)$ tidak setuju, 49 orang $(59.0 \%)$ menyatakan setuju dan sisanya 17 orang (20.5\%) netral, 8 orang $(9.6 \%)$ menyatakan sangat setuju, 70 orang $(84.3 \%)$ menyatakan setuju dan sisanya 3 orang (3.6\%) netral, dan 2 orang (2.4\%) tidak setuju;

Data hasil penelitian atas persepsi responden mengenai sistem pelaporan : distribusi jawaban responden dari pertanyaan prosedur pelaporan kinerja. Dari 83 responden, 20 orang (24.1\%) menyatakan sangat setuju, 57 orang $(68.7 \%)$ menyatakan setuju dan sisanya 6 orang (7.2\%) netral, 16 orang (19.3\%) menyatakan sangat setuju, 49 orang (59.0\%) menyatakan setuju dan sisanya 18 orang $(21.7 \%)$ netral, 16 orang $(19.3 \%)$ menyatakan sangat setuju, 63 orang (75.9\%) menyatakan setuju dan sisanya 4 orang (4.8\%) netral, 21 orang $(25.3 \%)$ menyatakan sangat setuju, 57 orang $(68.7 \%)$ menyatakan setuju dan sisanya 5 orang $(6.0 \%)$ netral, 16 orang $(19.3 \%)$ menyatakan sangat setuju, 59 orang $(71.1 \%)$ menyatakan setuju dan sisanya 8 orang $(9.6 \%)$ netral, 14 orang $(16.9 \%)$ menyatakan sangat setuju, 62 orang $(74.7 \%)$ menyatakan setuju dan sisanya 7 orang $(8.4 \%)$ netral;

Data hasil atas persepsi responden mengenai akuntabilitas kinerja instansi pemerintah : distribusi jawaban responden dari pertanyaan adanya keterkaitan yang erat antara pencapaian kinerja dengan perencanaan kinerja. Dari 83 responden, 16 orang $(19.3 \%)$ menyatakan sangat setuju, 59 orang $(71.1 \%)$ menyatakan setuju dan sisanya 8 orang (9.6\%) netral, 16 orang (19.3\%) menyatakan sangat setuju, 59 orang $(71.1 \%)$ menyatakan setuju dan sisanya 8 orang $(9.6 \%)$ netral, 8 orang $(9.6 \%)$ menyatakan sangat setuju, 60 orang $(72.3 \%)$ menyatakan setuju dan sisanya 8 orang $(9.6 \%)$ netral, 14 orang $(16.9 \%)$ menyatakan sangat setuju, 61 orang $(73.5 \%)$ menyatakan setuju dan sisanya 8 orang $(9.6 \%)$ netral, 17 orang $(20.5 \%)$ menyatakan sangat setuju, 63 orang $(75.9 \%)$ menyatakan setuju dan sisanya 3 orang $(3.6 \%)$ netral, 7 orang $(8.4 \%)$ menyatakan sangat setuju, 37 orang $(44.6 \%)$ menyatakan setuju, 37 orang $(44.6 \%)$ menyatakan netral dan sisanya 2 orang $(2.4 \%)$ tidak setuju, 7 orang $(19.3 \%)$ menyatakan sangat setuju, 59 orang (71.1\%) menyatakan setuju dan sisanya 8 orang $(9.6 \%)$ netral, 25 orang (30.1\%) menyatakan sangat setuju, 46 orang (55.4\%) menyatakan setuju dan sisanya 12 orang $(14.5 \%)$ netral; 
Data distribusi jawaban responden dari pertanyaan pimpinan dan seluruh komponen instansi, telah mampu menjabarkan tugas pokok dan fungsi instansi. Dari 83 responden, 15 orang (18.1\%) menyatakan sangat setuju, 55 orang $(66.3 \%)$ menyatakan setuju dan sisanya 13 orang (15.7\%) netral, 18 orang $(21.7 \%)$ menyatakan sangat setuju, 52 orang $(62.7 \%)$ menyatakan setuju dan sisanya 13 orang $(15.7 \%)$ netral, 10 orang $(12.0 \%)$ menyatakan sangat setuju, 63 orang (75.9\%) menyatakan setuju dan sisanya 10 orang (12.0\%) netral, 20 orang $(24.1 \%)$ menyatakan sangat setuju, 54 orang $(65.1 \%)$ menyatakan setuju dan sisanya 8 orang $(9.6 \%)$ netral serta 1 orang $(1.2 \%)$ tidak setuju, 17 orang $(20.5 \%)$ menyatakan sangat setuju, 50 orang $(60.2 \%)$ menyatakan setuju dan sisanya 16 orang $(19.3 \%)$ netral, 8 orang $(9.6 \%)$ menyatakan sangat setuju, 71 orang $(85.5 \%)$ menyatakan setuju dan sisanya 2 orang $(2.4 \%)$ netral serta 2 orang $(2.4 \%)$ tidak setuju.

Hasil uji reliabilitas instrumen pada penelitian ini menunjukkan bahwa nilai Cronbach's Alpha semua instrument penelitian berada pada rentang 0,7650,928 dan lebih besar dari nilai minimum yang disyaratkan $(0,70)$.

Hasil uji normalitas dengan menggunakan uji Kolmogorov Smirnov dan dengan melihat uji grafik, dapat disimpulkan bahwa data mempunyai distribusi normal. Jika nilai probabilitas asymp.sig (2-tailed) pada uji Kolmogorov Smirnov lebih besar dari 0,05 maka dapat dinyatakan bahwa data berdistribusi normal. Sebaliknya, jika probabilitas asymp.sig (2-tailed) lebih kecil dari 0,05 maka dapat disimpulkan bahwa data berdistribusi tidak normal Ghozali, (2013:160).

Uji mulitikolinearitas dapat dilihat dari nilai Tolerance dan VIF (Variance Inflation Factor). Nilai umum yang biasa dipakai dalam pengambilan keputusan adalah: Jika nilai Tolerance $>0,10$ dan nilai VIF $<10$, dengan demikian tidak terjadi multikolinearitas (Ghozali, 2013). Hasil dapat diperhatikan bahwa nilai Tolerance di atas 0,10 dan VIF dibawah 10, sehingga dapat disimpulkan bahwa tidak terjadi multikolineritas pada model regresi sehingga dapat melanjutkan pengujian data ke tahap selanjutnya. Sedangkan pengujian heteroskedastisitas pada penelitian ini dilakukan dengan uji Glejser dan dapat dilihat melalui chart Scatter Plot berdasarkan kriteria keputusan heteroskedastisitas dengan uji glejser.

Berdasarkan nilai probabilitas signifikansi di atas tingkat kepercayaan 5\%, maka dapat disimpulkan bahwa model regresi memiliki varian residual yang konstan (homokedastisitas) atau tidak terjadi heteroskedastisitas dalam model regresi.

Pengujian hipotesis pertama yaitu kejelasan sasaran anggaran dan sistem pelaporan berpengaruh secara simultan dan parsial terhadap akuntabilitas kinerja instansi pemerintah. Untuk melihat pengaruh secara simultan yaitu dengan menggunakan uji statistik $\mathrm{F}$, sedangkan untuk melihat pengaruh secara parsial, yaitu dengan menggunakan uji statistik $t$, dengan melihat nilai koefisien determinasi terlebih dahulu.

Uji koefisien determinasi $\left(\mathrm{R}^{2}\right)$ bertujuan untuk melihat seberapa besar variabel independen yang diteliti dapat menjelaskan variabel dependen. Namun jika variabel independen lebih dari satu maka sebaiknya untuk melihat kemampuan variabel memprediksi variabel dependen, nilai yang digunakan adalah nilai adjusted $\mathrm{R}^{2}$. 
Tabel 1. Koefisien Determinasi

\begin{tabular}{ccrcc}
\hline Model & $R$ & $R$ Square & Adjusted $R$ Square & Std. Error of the Estimate \\
\hline 1 & $.748^{\mathrm{a}}$ & .559 & .542 & .16046 \\
\hline
\end{tabular}

a. Predictors: (Constant), Sistem Pelaporan, Kejelasan Sasaran Anggaran

b. Dependent Variable: AKIP

Sumber : Data Penelitian, 2018

Dari table.1 diketahui nilai adjusted $\mathrm{R}^{2}$ sebesar 0,542, hal ini dapat mendeskripsikan bahwa variabel dependen mampu dijelaskan oleh variabel independen sebesar 54,2\% dan sisanya 45,8\% dijelaskan oleh variabel-variabel lain yang tidak disertakan dalam model regresi.

Uji statistik F (uji simultan) pada penelitian ini disebutkan bahwa variabel kejelasan sasaran anggaran, pengendalian internal, sistem pelaporan berpengaruh secara simultan terhadap variabel akuntabilitas kinerja instansi pemerintah, sebagaimana dijelaskan pada tabel 2.

Tabel 2. Uji F

\begin{tabular}{lcccccc}
\hline Model & & Sum of Squares & Df & Mean Square & F & Sig. \\
\hline 1 & Regression & 2.579 & 3 & .860 & 33.393 & $.000^{\mathrm{b}}$ \\
& Residual & 2.034 & 79 & .026 & & \\
& Total & 4.613 & 82 & & & \\
\hline
\end{tabular}

a. Dependent Variable: AKIP

b. Predictors: (Constant), Sistem Pelaporan, Kejelasan Sasaran Anggaran

Sumber : Data Penelitian, 2018

Pada hasil pengujian statistik F yang terlihat pada table 5.14, diperoleh nilai $F_{\text {hitung }}(33,393)>F_{\text {tabel }}(2,720)$ dan signifikansi sebesar 0,000 lebih kecil dari $a=$ 0,05, maka $\mathrm{H} 0$ ditolak dan $\mathrm{H} 1$ diterima atau hipotesis yang diajukan diterima. Hal ini berarti semua variabel independen (kejelasan sasaran anggaran dan sistem pelaporan) secara simultan berpengaruh terhadap variabel dependen (akuntabilitas kinerja instansi pemerintah) pada taraf signifikansi $\alpha=0,05$ atau tingkat kepercayaan 95\%.

Uji statistik $t$ bertujuan mengetahui besarnya pengaruh variabel independen secara sendiri-sendiri (parsial) terhadap variabel dependen.

Tabel 3. Uji t

\begin{tabular}{lcccccc}
\hline & \multicolumn{2}{c}{$\begin{array}{c}\text { Unstandardized } \\
\text { Coefficients }\end{array}$} & \multicolumn{2}{c}{$\begin{array}{c}\text { Standardized } \\
\text { Coefficients }\end{array}$} & & \\
\cline { 2 - 4 } Model & $\mathrm{B}$ & Std. Error & Beta & $\mathrm{t}$ & Sig. \\
\hline 1(Constant) & 1.254 & .308 & & 4.071 & .000 \\
Kejelasan Sasaran Anggaran & .039 & .050 & .063 & .791 & .431 \\
Sistem Pelaporan & .181 & .080 & .203 & 2.268 & .026 \\
\hline
\end{tabular}

a. Dependent Variable: AKIP

Sumber : Data Penelitian, 2018

Berdasarkan hasil pengujian pada tabel 3, maka secara parsial pengaruh masing-masing variabel independen terhadap variabel dependen diuraikan sebagai berikut : Variabel kejelasan sasaran anggaran $\left(X_{1}\right)$ memiliki tingkat signifikansi sebesar 0,431 lebih besar dari $a=0,05$ dan t-hitung $(0,791)<\mathrm{t}$-tabel $(1,664)$, dengan demikian $\mathrm{H} 0$ diterima dan $\mathrm{H} 1$ ditolak. sehingga dapat 
disimpulkan bahwa variabel kejelasan sasaran anggaran tidak berpengaruh signifikan terhadap akuntabilitas kinerja instansi pemerintah. Variabel sistem pelaporan $\left(\mathrm{X}_{2}\right)$ memiliki tingkat signifikansi sebesar 0,026 lebih kecil dari $\alpha=0,05$ dan t-hitung $(2,268)>$ t-tabel $(1,664)$, dengan demikian H0 ditolak dan H1 diterima.

$$
\mathrm{Y}=1,254+0,039 \mathrm{X}_{1}+0,181 \mathrm{X}_{2}
$$

Dari persamaan regresi linear di atas dapat dijelaskan bahwa : Konstanta (a). Nilai konstanta sebesar 1,254 berarti jika variabel independen dianggap nol (0) maka nilai variabel akuntabilitas kinerja instansi pemerintah akan sebesar 1,254. Kejelasan sasaran anggaran $\left(X_{1}\right)$ terhadap akuntabilitas kinerja instansi pemerintah $(Y)$. Nilai koefisien kejelasan sasaran anggaran sebesar 0,039 berarti setiap kenaikan nilai kejelasan sasaran anggaran sebesar satu satuan maka nilai variabel akuntabilitas kinerja instansi pemerintah akan bertambah sebesar 0,039 dengan asumsi variabel independen yang lain dalam model regresi adalah tetap. Sistem pelaporan $\left(\mathrm{X}_{2}\right)$ terhadap akuntabilitas kinerja instansi pemerintah $(\mathrm{Y})$. Nilai koefisien sistem pelaporan sebesar 0,181 berarti setiap kenaikan nilai variabel sistem pelaporan sebesar satu satuan maka nilai variabel akuntabilitas kinerja instansi pemerintah akan bertambah sebesar 0,181 dengan asumsi variabel independen yang lain dalam model regresi adalah tetap.

Secara keseluruhan dapat dilihat bahwa koefisien dari seluruh variabel independen bertanda positif namun tidak signifikan pada variabel kejelasan sasaran anggaran. Hal ini berarti bahwa hubungan antara kejelasan sasaran anggaran dan sistem pelaporan dengan akuntabilitas kinerja instansi pemerintah adalah positif di mana jika semakin bertambah nilai variabel kejelasan sasaran anggaran dan sistem pelaporan maka akan semakin meningkat pula akuntabilitas kinerja instansi pemerintah di lingkungan Pemerintah Desa di Kecamatan Sakra Barat.

Pengujian hipotesis kedua dilakukan menggunakan uji residual dengan variabel pemoderasi komitmen organisasi. Penggunaan variabel pemoderasi ini dimaksudkan untuk membuktikan hipotesis kedua bahwa variabel komitmen organisasi $(Z)$ dapat memoderasi hubungan antara variabel kejelasan sasaran anggaran $\left(X_{1}\right)$ dan sistem pelaporan $\left(X_{2}\right)$ dengan variabel akuntabilitas kinerja instansi pemerintah (Y). Untuk dapat mengetahui pengaruhnya dilakukan persamaan regresi dengan 2 tahap sebagai berikut :

Pengujian tahap pertama dilakukan dengan meregresikan variabel independen terhadap variabel pemoderasi. Hasil regresi variabel independen terhadap variabel pemoderasi dalam penelitian ini dapat dilihat pada tabel 4 .

Tabel 4. Uji residual tahap I

\begin{tabular}{rlcc}
\hline \multirow{2}{*}{ Model } & & \multicolumn{2}{c}{ Unstandardized Coefficients } \\
\cline { 3 - 4 } & & B & Std. Error \\
\hline \multirow{2}{*}{1} & (Constant) & 3.472 & .574 \\
& Kejelasan Sasaran Anggaran & 0.154 & .093 \\
& Sistem Pelaporan & -.049 & .149 \\
\hline
\end{tabular}

Sumber : Data Penelitian, 2018

Dari Tabel 4 dapat kita ambil persamaan sebagai berikut.

$$
Z=3,472+0,154 X 1-0,049 X 2
$$


Nilai residual persamaan II dihasilkan dengan mengubah persamaan I menjadi absolut residual yang digunakan sebagai variabel independen. Dari hasil uji persamaan II akan diperoleh kesimpulan apakah variabel komitmen organisasi bisa dikatakan sebagai variabel pemoderasi yang memoderasi hubungan antara variabel independen dengan variabel dependen. Sebuah variabel bisa dikatakan sebagai variabel pemoderasi apabila nilai signifikansi < dari nilai $\alpha=0,05$ dan memiliki nilai koefisien yang negatif.

Berdasarkan nilai residual persamaan II maka model uji residual diformulasikan dalam bentuk persamaan II sebagai berikut :

$$
|\varepsilon|=1,162-0,236(Y)
$$

Berdasarkan hasil uji residual yang dilakukan diketahui bahwa tingkat signifikansi sebesar 0,011 lebih kecil dari $a=0,05$ dan koefisien regresi yang bernilai -0,236 sehingga dapat disimpulkan bahwa variabel komitmen organisasi merupakan variabel pemoderasi yang dapat mempengaruhi dengan signifikan hubungan antara variabel kejelasan sasaran anggaran $\left(\mathrm{X}_{1}\right)$ dan sistem pelaporan $\left(\mathrm{X}_{2}\right)$ dengan variabel akuntabilitas kinerja instansi pemerintah $(\mathrm{Y})$.

Hasil penelitian membuktikan bahwa pengaruh secara simultan dapat dilihat dari hasil uji F, dimana nilai Fhitung dari variabel independen (kejelasan sasaran anggaran, dan sistem pelaporan) secara serentak lebih besar dari nilai Ftabel pada tingkat signifikansi dibawah 0,05 sehingga dapat diambil keputusan H0 ditolak dan H1 diterima. Dengan demikian dapat dikatakan bahwa kejelasan sasaran anggaran, dan sistem pelaporan berpengaruh terhadap akuntabilitas kinerja instansi pemerintah desa di Kecamatan Sakra Barat Kabupaten Lombok Timur.

Pengaruh secara parsial dapat dilihat dari hasil uji $t$, dimana nilai thitung dari setiap variabel independen lebih besar dari nilai ttabel pada tingkat signifikansi dibawah 0,05 sehingga dapat diambil keputusan H0 ditolak dan H1 diterima. Artinya sistem pelaporan berpengaruh positif dan signifikan terhadap akuntabilitas kinerja instansi pemerintah desa di Kecamatan Sakra Barat Kabupaten Lombok Timur. Sedangkan variabel kejelasan sasaran anggaran nilai $t_{\text {hitung }}$ lebih kecil dari nila $t_{\text {tabel }}$ pada tingkat signifikansi di atas 0,05 sehingga dapat diambil kesimpulan $\mathrm{H} 0$ diterima dan $\mathrm{H} 1$ ditolak. Artinya kejelasan sasaran anggaran tidak berpengaruh signifikan terhadap akuntabilitas kinerja instansi pemerintah desa di Kecamatan Sakra Barat Kabupaten Lombok Timur.

Melalui uji residual dapat dilihat pengaruh moderating yang menunjukkan bahwa variabel komitmen organisasi dapat memoderasi hubungan antara kejelasan sasaran anggaran, dan sistem pelaporan dengan akuntabilitas kinerja instansi pemerintah desa di Kecamatan Sakra Barat Kabupaten Lombok Timur, hal ini terlihat dari nilai koefisien yang bernilai negatif dan tingkat signifikansi dibawah 0,05 .

\section{SIMPULAN}

Bahwa kejelasan sasaran anggaran dan sistem pelaporan secara simultan berpengaruh positif dan signifikan terhadap akuntabilitas kinerja pemerintah desa di Kecamatan Sakra Barat Kabupaten Lombok Timur. Secara parsial sistem pelaporan berpengaruh positif dan signifikan terhadap akuntabilitas kinerja instansi pemerintah, sedangkan kejelasan sasaran anggaran tidak berpengaruh 
terhadap akuntabilitas kinerja instansi pemerintah desa di Kecamatan Sakra Barat Kabupaten Lombok Timur, namun memiliki nilai positif. Sedangkan komitmen organisasi mampu memoderasi hubungan antaran kejelasan sasaran anggaran dan sistem pelaporan dengan akuntabilitas kinerja instansi pemerintah desa di Kecamatan Sakra Barat Kabupaten Lombok Timur.

Penelitian ini hanya di tingkat pemerintah desa di Kecamatan Sakra Barat sebagai sampel penelitian. Untuk penelitian selanjutnya disarankan memperluas wilayah atau menambah objek penelitian terkait akuntabilitas kinerja instansi pemerintah di lingkungan pemerintah daerah Kabupaten atau Provinsi.

\section{REFERENSI}

Abdullah, H. (2005). Pengaruh Kejelasan Sasaran Anggaran, Pengendalian Akuntansi dan Sistem Pelaporan terhadap Akuntabilitas Kinerja Instansi Pemerintah Daerah (studi empiris pada kabupaten dan kota di daerah istimewa Yogyakarta). KOMPAK: Jurnal Akuntansi, Manajemen Dan Sistem Informasi, 13, 37-67

Akbar, Rusdi. Robyn Pilcher, Perrin, (2012). Performance measurement in Indonesia: the case of local government. Pacific Accounting Review, Vol. 24 Iss 3 pp. 262 291.http:/ / dx.doi.org/10.1108/01140581211283878

Andarias, B. (2009). Pengaruh partisipasi dalam penyusunan anggaran, kejelasan sasaran anggaran dan struktur desentralisasi terhadap kinerja manajerial SKPD dengan pengawasan internal sebagai variabel moderating [Tesis]. Universitas Sumatera Utara.

Arens, A. A.,et al. (2008). Auditing dan Jasa Assurance. Terjemahan. Jakarta: Erlangga.

Barako, D. G., Hancock, P. \& Izan, H. (2006). Factors influencing voluntary corporate disclosure by Kenyan companies. Corporate Governance: An International Review, 14:2, 107-25.

Erlina dan Mulyani, Sri. (2007). Metodologi Penelitian Bisnis untuk Akuntansi dan Manajemen. Medan: USU Press.

Epstein, M. J., dan Freedman, M. (1994). Social disclosure and the individual investor. Accounting, Auditing and Accountability Journal. Vol. 7: 94-109.

Ghozali, I. (2014). Analisis Multivariat dan Ekonometrika. Semarang: Universitas Diponegoro.

Hafiz, Muhammad. (2016). Pengaruh kompetensi aparatur pemerintah, ketaatan pada peraturan perundang-undangan dan kejelasan sasaran anggaran terhadap akuntabilitas kinerja instansi pemerintah dengan komitmen organisasi dan kinerja manajerial sebagai variabel moderating (studi empiris pada SKPD Kabupaten Kampar) JOM Fekon, Vol. 4 Nomor 1 (Februari) 2017 Universitas Riau.

Harsanti, P. (2008). Faktor-faktor yang mempengaruhi akuntabilitas kinerja instansi pemerintah daerah Kabupaten Kudus. Penelitian Universitas Muria: Kudus

Ghozali, Imam. (2013). Aplikasi Analisis Multivariate dengan Program IBM SPSS Edisi-7. Badan Penerbit Universitas Diponegoro. Semarang.

(2016). Aplikasi Analisis Multivariate Dengan Program SPSS Edisi-8. Semarang : Badan Penerbit Universitas Diponegoro. 
Kenis, I. 1979. "Effects of Budgetary Goal Characteristics on Managerial Attitudes, and Performance", The Accounting Review.

Lembaga Administrasi Negara, Pedoman Penyusunan Pelaporan Akuntabilitas Kinerja Instansi Pemerintah. Jakarta: LANRI 2003.

Locke, E., Latham. (1984). Goal Setting. A motivational technique that works.Prentice Hall. Inc Englewood: New Jersey.

Lubis, Ade Fatma. 2016. Metode Penelitian Akuntansi dan Format Penulisan Tesis. Medan: USU Press.

Luthans, Fred. 2006. Prilaku organisasi. Edisi 10. Yogyakarta: Andi.

Mahsun, Mohamad. (2006). Pengukuran Kinerja Sektor Publik. Edisi Pertama. Yogyakarta: BPFE Yogyakarta.

Mardiasmo. (2009) . Akuntansi Sektor Publik. Penerbit Andi: Yogyakarta.

Mulyadi. (2002). Auditing Buku 1. Edisi Keenam. Jakarta: Salemba Empat

Munandar, M, 2001. Budgeting, Perencanaan Kerja, Pengkoordinasian Kerja, Pengawasan Kerja. Edisi 1. Cetakan 14. BPFE: Yogyakarta.

Nouri, H. dan R. J. Parker. 1998. The Relationship Between Budget Participation And Job Performance: The Roles Of Budget Adequacy And Organizational Commitment. Accounting, Organization and Society. Vol 23. No5/6 pp.467-483.

Nusantoro, Sunarno Agus. (2009). Efektivitas Penerapan Sistem Akuntabilitas Instansi Pemerintah (SAKIP) di Kabupaten Tasikmalaya [Tesis]. Depok: Universitas Indonesia.

Rama, Dasaratha V dan Jones Federick L. 2008. Sistem Informasi Akuntansi. Jakarta: Salemba Empat.

Republik Indonesia. Undang-Undang Nomor 25 Tahun 1999 tentang Perimbangan Keuangan antara Pemerintah Pusat dan Daerah. Jakarta.

Sanusi, Anwar. (2011). Metodologi Penelitian Bisnis. Jakarta : Penerbit Salemba Empat.

Septiyani, Anna. (2010). Pengaruh kejelasan sasaran anggaran, pengendalian akuntansi terhadap akuntabilitas kinerja instansi pemerintah daerah dengan komitmen organisasi sebagai variabel pemoderasi (studi empiris pada Pemerintah Kota Yogyakarta [Skripsi]. Yogyakarta: Universitas Muhammadiyah Yogyakarta.

Soegiarto Soekidjan, Sp.KJ. (2009). Komitmen Organisasi Sudahkah Menjadi bagian Kita. Jakarta: Bineka Cipta.

Sopiah. 2008. Prilaku Organisasional. Penerbit Andi: Yogyakarta.

Sugiyono. 2007. Statistik untuk Penelitian. Bandung.

Umar, Husein. (2008). Metode Penelitian untuk Skripsi dan Tesis Bisnis. Jakarta. PT. Rajagrafindo Persada.

Wahyuni, Raja, Surya, Adri Satriawan, dan Savitri, Enni. (2013). Pengaruh Kejelasan Sasaran Anggaran, Pengendalian Akuntansi dan Sistem Pelaporan Terhadap Akuntabilitas Kinerja Instansi Pemerintah (Studi Pada SKPD Kabupaten Rokan Hulu). Jurnal Jurusan Akuntansi Fakultas Ekonomi Universitas Riau. (http:/ / www.portalgaruda.org, diakses tanggal 12 Desember 2016).

Wardhana, Surya. Pengaruh kompetensi pada akuntabilitas kinerja instansi pemerintah dengan komitmen organisasi sebagai variabel moderasi di 
Kabupaten Tabanan. E-Jurnal Ekonomi dan Bisnis Universitas Udayana 2015:571-591. Bali.

Welsch, Hilton, Gordon. (2000). Anggaran Perencanaan dan Pengendalian Laba. diterjemahkan oleh Purwatiningsih dan Maudy Warouw. Buku Satu Jakarta: Salemba Empat. 